\title{
ВИРЏИНИЈА ВУЛФ
}

Таласи сјећања

Седамдесет пет година је од како је Вирџинија Вулф потражила спас од авети које су је прогониле у таласима ријеке Уз, чврсто стиснувши два камена и оставивши таласе сјећања иза себе.

Није могла да се суочи са могућношћу да буде распарчана у комадиће. Вода јој је била пријатељ од како је била дијете у Корнволу. Води се могло вјеровати. Вода је значила мир. Вода ју је могла примити са достојанством које joj је било потребно, осјећала је: стварно га је заслужила (Poole 1978: 279).

Сјећања на Вирџинију Вулф и код читалаца и код истраживача навиру у таласима претапајући реално и фикционално, теоријско и историјско. Не говоре нам само о њој. Говоре и о нама: њеним читаоцима и истраживачима. Говоре о нашим сталним покушајима да се некако приближимо њеној заоставштини. Иако одсутна, Вирџинија Вулф је, ипак. присутна и као да ослушкује разнолике покушаје кроз вријеме да јој се приближимо, да се приближимо оној тајни коју је упорно, често драматично, покушавала да открије: оном тамо „иза“, оном непознатом, несазнатљивом. Ипак, што смо се више приближавали тајнама њене рањиве душе и бриљантног ума кроз могућа тумачењима њених сложених, често болних књижевних 
дјела, (фикционалних и нефикционалних), нови таласи разнородних перспектива стално су навирали тјерајући нас да и даље покушавамо.

Поглед уназад казује нам о ранијим покушајима, о томе да су многи први књижевни критичари тумачили дјела Вирџиније Вулф, углавном фикционалне текстове, кроз теорије Анрија Бергсона, акцентирајући ток свијести (Marcus 1997: 2). Седамдесете године донијеле су обновљено интересовање за њена дјела с акцентом на одсуству субјективности и безличном универзуму. Деведесте су донијеле и постмодернистичке приступе. И тако редом...У таласима сјећања данас назире се још нешто: многа од ових раних тумачења стваралаштва Вирџиније Вулф у Британији често су превиђала њену улогу у друштвеним и политичким превирањима доба у коме је живјела, занемарујући при томе њене нефикционалне текстове. Тако је, на примјер, Дејвид Дејчиз (David Daiches) описује као „високо привилеговану естету са мало знања или разумјевања политике и са само површним познавањем друштва осим више средње класе којој је припадала.“(1945: 10)

Морамо нагласити један чест парадокс када је питању рецепција “домаћих” писаца у Великој Британији: у то вријеме у континенталној Европи и Америци рецепција Вирџиније Вулф била је далеко повољнија него у њенох родној груди. Иако се акценат критике ставља на прозу, примјећује се и значај њених нефикционалних текстова. Тако, Ерих Ауербах (Erich Auerbach, 1946) у својој студији Мимезис расправља о њеном експерименталном приступу емоцијама и мислима у роману Ка светионику и закључује да је њено преговарање са унутрашњим и спољашњим свијетом готово искључило уочавање њеног доприноса књижевној критици 1970-их, што увиђа и француски критичар Жан Гиге (Guiguet) у студији Вирииға Вулф и юена 
дјела (Virginia Woolf and her Works) у којој се осврће на њену феминистичку политику, њене есеје, памфлете, њену свијест о сопственом друштву, а чиме антиципира феминистичко откривање Вирџиније Вулф као друштвеног и политичког мислиоца (Wood 2010: 24). Жан Гиге је отворио пут тумачењу дјела Вирџиније Вулф у феминистичком кључу током 1970-их у другом таласу који га је политички оснажио, а који је одиграо важну улогу у буђењу савременог разумјевања њених размишљања о друштву, што је довело до значајног превредновања њеног дјела: до његовог сагледавања у цјелости. То је утицало да се њена дјела Conствена соба и Три гвинеје тумаче и као један аспект њене шире политичке позиције. Њена сада лако препознатљива сентенца да женама треба допустити да пишу као жене (Сопствена соба, 97) распалила је дискусије с обје стране Атлантика. Тако, Илејн Шоволтер (Elaine Showalter) у својој критици Њихова сопствена књижевност (A Literature of Their Own) одбацује феминистчку позицију Вирџиније Вулф и сугестију да идеалан писац мора имати андрогине погледе (Wood 2010: 24-25). Издвојићемо глас и Џејн Маркус (Jane Markus), која 1981. године изједначава покушај Вирџиније Вулф да прати трагове историје женског искуства у њеној критичкој прози са „активним политичким дјеловањем посвећеног социјалистичког феминизма"(Wood 2010: 24-25).

У периоду који ће услиједити долази до значајног помјерања акцента у анализи књижевности, што ће помјерити границе у тумачењу поетике Вирџиније Вулф. Средином седамдесетих пост-структуралистички орјентисане феминистичке теоретичарке (француски феминизам) окрећу се ка језику и његовим конотацијама у односу на род у дјелима женских писаца и њиховим могућностима да изразе женско 
писмо. Најприје се чује глас Јулије Кристеве која препознаје женске гласове као „визионарске“, да би се убрзо чули слични гласови англо-америчких феминистичких књижевних критичарки и критичара крајем 1970-их и 1980-их који су се дефинисали под утицајем француске концепције језика која укључује и Другост. У овом периоду све је више критичарки и критичара који експерименталну естетику Вирџиније Вулф читају као политичку. Тако, Торил Мои (Toril Moi,1985) сугерише примјену кључа Јулије Кристеве којим ће се утврдити одбијање Вирџиније Вулф да у есејима примијени такозвану рационалну или логичку форму писања с циљем да користи језик да би трансформисала „симболички ред ортодоксног друштва од изнутра“(Wood 2010: 26). Алис Вуд (Alice Wood) издваја и критички глас Макико Миноу-Пинкни (Makiko Minow-Pinkney), која истиче како се експериментални романи Вирџиније Вулф могу посматрати и као феминистичка субверзија самих дефиниција наратива, писања и субјекта - патријархалног друштвеног поретка. Она закључује да су многи феминистички критичари гледали попријеко на ова тумачења нарочито након појаве студије Невоље са родом (1990) Џудит Батлер (Judith Butler), али упркос томе значај француског феминизма не може се занемарити. Напротив.

Велику улогу у феминистичком тумачењу Вирџиније Вулф као књижевнице с јасним политичким ставом крајем 1970-их и 1980-их (1975-1984) одиграло је објављивање њених писама и дневника (5 томова дневника, 1915-1940, 6 томова писама, 1888-1941) у којима реагује на историјски, културолошки и интелектуални контекст времена у коме је стварала, а који дубоко залазе и у њен приватни и јавни живот. У овим понекад жанровски тешко одредивим текстовима ипак није тешко идентификовати њена политичка мишљења, 
њене страхове, али и спољашње утицаје који су формирали ставове Вирџиније Вулф у односу на положај жене у британском патријархалном друштву. Има много разлога да се акценат будућих истраживања значајније премјести на ове таласе сјећања у односу према њој и њеном стваралаштву.

Међутим, ускоро васкрсава још један талас критике, битан за тумачење поетике Вирџиније Вулф, талас који је скренуо пажњу многих феминистичких истраживача. У питању је текстуална критика која испитује њене раније верзије романа Вирџиније Вулф и њене рукописе још од 1960-их, посебно од како је Чарлс Хофман (Charles G. Hofmann) указао на њих. Хофман је покушао да одговори на једно од кључних питања за тумачење поетике Вирџиније Вулф: шта нам различите варијанте неког њеног романа могу казати о томе како је налазила пут до одређених формалних структура. Он је овим питањем само указао на могућност постављања и многих других питања која ће се односити на сам тон и предмет дјела (Wood 2010: 26).

Декаду касније, (1977) Билтен државне библиотеке Њујорка истраживаће социјалне и политичке импликације у њеним дјелима Године и Три гвинеје: трагове сексуалне политике, формалну структуру њеног дјела Године, као ону структуру која је супротна фашистичко;генезу поментих дјела и много тога (Wood 2010: 28). Неопходно је истаћи да су овакви и слични феминистички приступи испитивању дјела Вирџиније Вулф (1970-их и 1980-их) од посебног значаја будући да истовремено преиспитују и саму феминистичку критику: у којој мјери се деформише, трансформише или ојачава у тренутку док испитује роман у јавном простору; у којој мјери је сама критика средство помоћу кога се може продријети кроз површину текста даби се на свјетлост избацили „потопљени“ текстови (Wood 2010: 29). 
Нови талас критике у тумачењу дјела Вирџиније Вулф, који истражује њена дјела у оквиру културолошког контекста који их је дефинисао, а дошао нам је у виду Новог историзма 1980-их. Његове корјене проналазимо у пионирској студији Алекса Звердлинга (Alex Zwerdling) 1986. године, у којој указује на заокупљеност Вирџиније Вулф односом ликова (мушких и женских) и друштвене средине која их обликује, али и најчешће деформише. Ова студија консолидовала је напоре феминистичких критичара да деконструишу Вирџинију Вулф као изоловану естету и извршила је значајан утицај на тумачење њених дјела као истовремени производ и коментар доба у коме је живјела (Wood 2010: 28-29).

Таласима никада краја па се у једном тренутку може уочити да долази и до значајног преклапања два таласа: циљева и метода феминистичке и историјске критике. Најзначајнији утицај дошао је из пера Гилијан Бир (Gillian Beer) која у својим есејима поново контекстуализује дјела Вирџиније Вулф у оквиру њеног викторијанског васпитања и тиме утиче на појаву “феминистичког-историзма” крајем 1980-их, који ће се, по мишљењу Алис Вуд, развити и супротставити феминизму који почива на лингвистици, а који заступају критичари који пишу у традицији француског феминизма у то вријеме (Wood 2010: 30).

Следећи талас изазваће феминистичку, историјску и текстуалну критику 1970-их и 1980-их тврдећи да је Вирџинија Вулф ипак само елитистичка представница високе културе, јер јој није много стало до „широких народних маса“. Било је и оних који су је бранили, показује Алис Вуд, као нпр. Лора Маркус (Laura Marcus) која је тврдила да допринос Вирџиније Вулф освјетљавању друштвених прилика није ништа мањи од доприноса истакнутог марксистичког критичара - Терија Иглтона (2010: 31). Ови супротстављени гласови само 
ће распалити расправе у књижевној критици у току наредне двије деценије и натјераће је да прошири поље својих истраживања и стави нагласак и на начин на који дјела Вирџиније Вулф представљају одговор, реакцију, критику цјелокупног британског друштва и прилика у Европи, а не само мале класе образованих „татиних“ кћерки, како је најчешће њено дјело тумачено до тада. Поменимо само једно мјесто из Џон Леманове (John Lehmann) биографије Вириинија Вулф у коме он подсјећа на то да је Вирџинија Вулф већ у Сопственој соби указала на опасности од Мусолинијевог фашизма након чега је услиједио долазак Хитлера на власт, те почео прогон Јевреја заједно са припремама за рат. Леман наводи ријечи једног женског лика Вирџиније Вулф, Пеги, изједначавајући их са доживљајем свијета Вирџиније Вулф у том тренутку:

„како може ико бити 'срећан', питала се, у свијету који пуца од јада. На сваком углу улице умрлица објављује смрт; или оно још горе - тиранију; бруталност; мучење; пад цивилизације; крај слободе. Ми овдје, помислила је, само се скривамо испод лишћа које ће бити уништено..." (1975: 97)

На њена рањена осјећања надовезују се константна размишљања о томе како дефинисати вриједности и идеал реформисаног друштва од кога је одбила све почасти, јер је била убијеђена да је корумпирано. Ријечи Вирџиније Вулф данас звуче дирљиво, инспиративно и охрабрујуће:

Оне морају бити креативне да би дјеловале, не смију само крититиковати. Критиковањем образовања помогли би да се створи цивилизовано друштво које штити културу и интелектуалну слободу. Критиковањем религије покушали би да ослободе религиозни дух од њеног садашњег 
служинства, и помогле би, ако би било потребно, да се створи нова религија заснована на Новом завјету, али, која би се можда значајно разликовала од религије која почива на њеним основама (1975: 98).

АлисВуд сматра да је један од разлога за помјерање акцента са унутрашњег на спољашњи приступ крајем 20. и почетком 21. вијека објављивање цјелокупних есеја Вирџиније Вулф (The Essays of Virginia Woolf, 1986, 1994, 2009) уз могућност приступа њеним новинарским текстовима, који су раније ријетко изучавани. Деведесете их откривају алии учвршћују позицију Вирџиније Вулф: Бет Керол Розенберг (Beth Carole Rosenberg, 1995) сврстава је међу најзначајније књижевнице 20. вијека, док Лејла Бронсан (Leila Bronsan (1997) истиче финансијски, професионални и интелектуални значај њених новинских чланака (600 чланака) и при том тврди да су значајно утицали на њен неортодоксни стил. Она истиче и њен приступ култури и књижевности Wood 2010: 32). Џулијет Дјусинбер (Juliet Dusinberre, 1997) долази до једног занимљивог закључка: до кључног преображаја у поетици Вирџиније Вулф дошло је оног тренутка када више није видјела себе као књижевницу, већ као књижевну критичарку (Wood 2010: 33).

Крај вијека доноси и студију Лоре Маркус Писичи u нихова дјела:Вириинија Vulf (Writers and Their Works: Virginia Wolf) инспирисану погледима Вирџиније Вулф на род и идентитет, субјективност и сопство, патријархалност и милитаризам, историју и садашњост (Wood 2010 34). Истраживање цјелокупног фикционалног и нефикционалног корпуса Вирџиније Вулф показује, премаЛори Маркус, значајно присуство друштвеног искључивања, порицање социјалне правде и вредновања људских бића. Лора Маркус, међутим, не искључује помјерање фокуса у модернистичкој парадигми са 
спољашњег на унутрашњи план, али исто тако показује да је реалност на коју Вулфова првенствено циља прије свега друштвена. Ово значи да је једна од најважнијих тема романа Вирџиније Вулф утицај (потчињавање: кроз религију, науку или друштвене конвенције) историјских прилика, политичке климе и друштвених околности на живот појединца. Угрожавање индивидуалности представља константну пријетњу за многе ликове: од Кларисе до Септимуса, закључује Лора Маркус.

Наредни талас у изучавању поетике Вирџиније Вулф доноси још значајније помјерање акцента са фикционалних на нефикционалне текстове. Тако, Гаултјери (Gualtieri, 2000) истиче допринос Вирџиније Вулф есеју не само као књижевној форми, већ као извору из кога се јасно види њен активни ангажман у књижевним и друштвеним дебатама оног времена (Wood 2010: 33). Неки критичари 2000-их, као Ана Снејт (Anna Snaith, 2000) на примјер, испитују јавну улогу Вирџиније Вулф у критици друштва, дихотомију приватног и јавног и утицаје ове дихотомије на њено стваралаштво, рецепцију њених дјела и улогу интелектуалке која дјелује у јавном простору (Wood 2010: 33).

У овом штуром прегледу незаобилазно је поменути збирку есеја под насловом Вириинија Вулф и фашизам (Virginia Woolf and Fascism) коју је уредио Павловски (Pawlowski), а која испитује њен допринос јавним дебатама које су се односиле на фашизам и критику британског патријархата (Wood 2010: 33-34). Значајан је допринос и Кристине Фруле (Christine Froula, 2005) која истраживала поетику Вирџинију Вулф и њену улогу у блумбзберијевском јавном мњењу и дошла до закључка да је имала централну улогу у току међуратног периода (Wood 2010: 34).

Неопходно је поменути још један талас који је увукао у себе један број студија које се односе на перио- 
дику, нову грану књижевних и културолошких студија са њеним истакнутим истраживачима Колијером, Летманом, Шолзом (Collier, Lathman, Scholes). Вјерујемо да ће се након појаве шестог тома есеја (2010) Вирџиније Вулф, који сви заједно обухватају период од 19291941, појавити нова истраживања са акцентом на њен допринос културолошким тумачењима доба у коме је живјела и стварала, будући да се ова тенденција већ назире, нарочито када су у питању текстови које су настали у њеном каснијем стваралаштву.

Поменута тенденција назире се у раније поменутој студији из пера Алис Вуд: Касна културолошка критика Вирииније Вулфб (Virginia Woolf's Late Cultural Criticism), која баца свјеж поглед на друштвене и политичке ставове Вирџиније Вулф у каснијем периоду њеног стваралаштва, примењујући по први пут генетско-феминистичко-историјско истраживање развоја њене критике културе у периоду од 1931-1941. Истраживање Алис Вуд инспирисано је све чешћим препознавањем улоге Вирџиније Вулф као коментаторке британског савременог друштва и политике током посљедње деценије њеног живота с циљем да се нагласе њени покушају реаговања на мноштво социјалних, политичких и економских питања у британском друштву. Управо због тога Алис Вуд у поменутој студији дефинише Вирџинију Вулф као критичарку британске културе да би истовремено нагласила мноштво тема које термин „култура“ обухвата, а којима се Вирџинија Вулф обраћа у овом периоду: од друштвене и економске позиције жене у друштву до савременог конзумеризма; од односа књижевности и политике до сложених односа између патријархата, империјализма и рата. Алис Вуд прати генезу критике културе Вирџиније Вулф и показује развој њених друштвених и политичких коментара током 1930-их и почетком 1940-их 
и њихову везу према модернистичким експериментима с почетка њене каријере. Она закључује да формалне иновације у касном периоду стваралаштва Вирџиније Вулф и блиска веза између њих и њеног политичког радикализма подједнако испитују двије истакнуте фазе њеног стваралаштва: модернистичке 1920-их и политичке 1930-их. Ово само значи, закључује Алис Вуд, да је касна културолошка критика Вирџиније Вулф, која представља реакцију на економску, социјалну и политичку кризу која је владала у Европи у период од 1930-1941, у истој мјери одјек њених раних естетичких погледа (2010: 41).

У покушају да пратимо путеве дефинисања поетике Вирџиније Вулф, не можемо а да се не осврнемо на њене романе из 1930-их и њихов однос према историји. На то нас упућује и Џулија Бригс (Julia Briggs) која указује на саму суштину њене поетике рекавши да њени романи „испитују људску природу: шта је то што чини нашу свијест када смо сами а шта када смо са другима, како живимо у времену, у којој мјери је наша природа одређена случајношћу рода, класе и историјског момента“(2000: 72). Бригсова даље развија ову тезу тврдећи да „Први светски рат представља онај кључни моменат, ону црту која раздваја прошлост и садашњост, која се увијек доживљава као амбис или вододелница“ (2000: 73). Тако, наставља Бригсова, Јакобова соба (1922) слика енглеску средњу класу прије рата, а Госпођа Даловеј (1925) даје њен портрет послије рата. (72) Роман Ка светионику (1927) их контрастрира. Први свјетски рат јесте прекретница, али било је потребно да прође још неколико година прије него што је Вирџинија Вулф почела озбиљније да размишља о трагедији и комедији викторијанског доба, истиче Бригсова. То ће се десити са објављивањем Орланда (1928), дјела у коме ће дефинисати дух тог доба као доба болних промјена. 
У Орланду, Вулфова описује викторијанско доба у виду мрачног облака који се шири и језиве депоније која је истовремено извор раста и плодности, али и опште депресије и распадања. То је доба које карактерише обиље и неконгруентност, са најчуднијим одликама нагомиланим у виду огромног трофеја који се протеже од узвишеног до профаног, од кристалних палата до врећастих панталона. То доба даље карактерише репресија и претјерано поштовање према браку и породичном животу (2000: 73).

Остали аутори окупљени око поетике Вирџиније Вулф у Кембрицовом приручнику Вириинији Вулф освјетљавају значајне аспекте њених фикционалних и не-фикционланих текстова. На њих се у предговору осврће Cjy Poy (Sue Roe) истичући бриљантан ум Вирџиније Вулф: њену интелектуалну и креативну снагу, радну упорност, њен дијалог са временом у коме је живјела, њену расправу са историјом, њено мноштво персона, умова који „разговарају једни са другима“ (2004: XIII). Иако свјесна да припада свијету модерне, Вирџинија Вулф је стално разговарала са прошлошћу одакле је црпила материјал и за своје фикционалне и не-фикционалне текстове, наставља Сју Роу и додаје да је сво вријеме одржавала чврсту везу између есеја и прозе, док се њена „преокупираност публиком и приступом тржишту очитовала у њеним стратегијама за објављивање не-фикционалних текстова“ (2004: XV). У том смислу показивала је отпор према цензури, корупцији и хијерархији, али и жељу да истражи унутрашњи свијет човјекове душе у својим дјелима: помирила је потребу да заради сопствену кору хлеба и истовремено комуницира са својом публиком. Како у фикционалним тако и у не-фикционалним текстовима увијек је имала на уму вриједности заједнице којој је припа- 
дала. У својим есејима никада није упућивала на себе: говорила је из позиције књижевног и културолошког истиче Хермиони Ли (Hermione Lee), која наводи оно што Вирџинија Вулф доживљава као „витални парадокс и изазов за писца-есеја: 'Никада не бити Ти, па ипак, увијек““ (2004: 107).

Поменимо на крају овог штурог представљања неких аутора из поменутог приручника, који значајно освјетљавају нашу тему, и закључак Сузан Селерс (Susan Sellers) који се односи на њено истраживање дневника Вирџиније Вулф. Она наводи једну одредницу из дневника Вирџиније Вулф, из времена када је тражила одговарајућу форму, у којој каже:

Испред мене вијори сјенка некакве форме којој дневник може тежити. Можда временом схватим шта је то што човјек може створити од тог лепршавог, цикличног материјала што се живот зове; да му пронађе другу сврху од оне коју ја имам на уму, с пуном свијешћу и скрупулозно, у фикцији (2004: 122).

Форму дневника, која би јој одговарала, Виргинија Вулф није пронашла. због чега није дозволила њихово објављивање у цјелости, али формулу за њихово тумачење пронашла је Сузан Селерс у постмодернистичком кључу који је откључао неред, животни ток и инклузивност покушавајућу да дефинише „ону нову форму писања коју је Вирџинија Вулф тражила током цијеле каријере“ (2004: 122). Један кратак одломак из В тома дневника Вирџиније Вулф илуструје и једно и друго: (субота 13. април 1940.)

„Прво ратно дробљење“ - тако га Винстон назива. Њемци напали Норвешку. Битке се бију. Цуре вијести. Неки кажу да је ово Хитлеров крај. ...Диван прољећни дан пред нама; ... надлијећу авиони...пишем, јер је то 
дробљење....уморна од писања предавања. Морам себи да олакшам. То су моји мотиви....вечера у пећници. Месо лоше и тек по који залогај. Јаја за вечеру. Риба за Ленарда за мене макарони. И вријеме је... (Woolf 1985)

Вратимо се Алис Вуд са којом се није тешко сложити у следећем: постоји тијесна веза између културолошке критике и биографског новинарства Вирџиније Вулф у коме се залаже за поновну феминистичку оцјену многих потиснутих или пак прећутаних гласова у британском партијархалном друштву. Биографија сваке жене и мушкарца вриједна је помена, показује нам Вирџинија Вулф у својим дневницима, писмима и историјама, оних наизглед обичних, али и оних истакнутих у умјетности, науци, политици или „у оквиру ограниченог простора њиховог дома“ (2010: 54). Биографије су јој послужиле и као подлога на којој је „конструисала колективну историју женског искуства која оцртава и критикује вриједности културе, друштвене родне улоге и економске околности које су женама одређивале приступ образовању и професији“" (2010: 56).

То јој јесу омогућиле биографије, али и сви остали текстови који нам је оставила у завјештање: фикционални и не-фикционални, њена сопствена соба, но, прије свега, нужност, жеља, потреба да ствара (Дојчиновић 2015: 144). Опстајање жеље јесте и одговор на тему којом се бавимо у овом раду: жеља је предуслов настанка како фикционалних тако нефикционалних текстова Вирџиније Вулф, критике и историје истовремено. 


\section{Литература}

Auerbch, Erich. The Representation of Reality in Western Literature. Princeton: Princeton University Press, 1953.

Briggs, Julia. "The novels of the 1930s and the impact of history". The Cambridge Companion to Virginia Woolf. Sue Roe and Susan Sellers (Eds). Cambridge: Cambridge University Press, 2000.

Daches, David. Virginia Woolf, London: Poetry London, 1945

Dojčinović, Biljana. Pravo sunca: drugačiji modernizmi. Novi Sad: Akademska Knjiga, 2015.

Lee, Hermione. "Virginia Woolf's Essays". The Cambridge Companion to Virginia Woolf". Sue Roe and Susan Sellers (Eds). Cambridge: Cambridge University Press, 2004.

Lehman, John. Virginia Woolf. London: Thames and Hudson, 1975.

Marcus, Laura. Writers and Their Work: Virginia Voolf. UK: Northcote House Publishers Ltd, 1997.

Poole, Roger. The Unknown Virginia Wolf. Cambridge: Cambridge University Press, 1978.

Roe, Sue. „Preface”. The Cambridge Companion to Virginia Woolf“. Sue Roe and Susan Sellers (Eds). Cambridge: Cambridge University Press, 2004.

Sellers, Susan. "Virginia Woolf's Diaries and Letters". The Cambridge Companion to Virginia Woolf". Sue Roe and Susan Sellers (Eds). Cambridge: Cambridge University Press, 2004.

The Diary of Virginia Wolf. Anne Olivier Bell (Ed.), Penguin Books, 1985.

Wood, Alice. “The Development of Virginia Woolf's Late Cultural Criticism, 1930-1941“, PhD thesis submitted to De Montfort University, June 2010. 